\title{
The Effect of Cooperative Learning Implementation Of Numbered Head Together Type on Students Cooperation Ability In Elementary School
}

\author{
Abdul Hakim ${ }^{1}$, Yulia $^{2}$ \\ \{abdulhakim@unm.ac.id ${ }^{1}$,Yulia@unm.ac.id $\left.{ }^{2}\right\}$ \\ ${ }^{1,2}$ Faculty of education, Universitas Negeri Makssar, Indonesia
}

\begin{abstract}
This study aims to describe the implementation of cooperative learning model numbered head together, and the ability to cooperate with students, and to know the effect of applying cooperative learning numbered head together to the ability to work together with students in SDN 15 in the city of Parepare. The ability to work together provides a large contribution to the success of student learning. Learning materials, approaches, models, or learning methods that are not suitable for building the ability to cooperate with students cause learning outcomes not optimal. To support the implementation of optimal learning and produce learning outcomes that meet the minimum completeness criteria, it is important for teachers to increase student collaboration in the learning process by applying the NHT type cooperative learning model. The research method used is a type of quantitative research with Quasi Experimental design research with variations of nonequivalent control group design. Data collection techniques used are observation, questionnaire and documentation. Data analysis techniques are descriptive statistics and inferential statistics where inferential data analysis carried out includes data normality test, data homogeneity test, and hypothesis test data. The results showed that the ability to cooperate with students increased after the application of the NHT type of cooperative learning model in the experimental class, this was seen from the average score of the posttest questionnaire on students' ability to work which reached 83.4.

Based on this it can be concluded that there is an effect of the application of the numbered head together type of cooperative learning model to the ability to collaborate students in Parepare 46 State Elementary School.
\end{abstract}

Keywords: cooperative learning, student ability.

\section{Introduction}

Education is a fundamental right of every human being which must be fulfilled by the government of a country. For the Republic of Indonesia Rights to education guaranteed in Chapter XA on Human Rights article $28 \mathrm{C}$, paragraph 1, which reads: Everyone has the right to develop themselves through the fulfillment of basic needs, entitled menapat education and gain the benefits of science and technology, art and culture to improve the quality of life and for the welfare of mankind.

Selanjutnnya in Chapter XIII of the Education and Culture Article 31 UUD 1945 paragraph 1 states that every citizen is entitled to education and paragraph 2 states, every citizen is obliged to follow basic education and the government must pay for it. The central government and local governments are obligated to provide service and convenience as well as ensuring the quality education for every citizen without discrimination, and shall ensure the availability of budget for implementation of education for every citizen. 
To describe in detail the mandate contained in the 1945 special education, the government and the DPR of mengeluakan Law on National Education System, the Law of the Republic of Indonesia Number 20 Year 2003 on National Education System Chapter II, Article 3 of the Functions and Purposes, which reads : the national education serves to develop the ability and character development and civilization of the nation's dignity in the context of the intellectual life of the nation, is aimed at developing students' potentials to become a man of faith and devoted to God Almighty, noble, healthy, knowledgeable, skilled, creative, independent and become citizens of a democratic and accountable.

In accordance with the above educational goals that education should be a forum for students to develop all their potential. So that it can form a character that can ultimately educate the nation.

Educators need to know more about how to design and program development activities, ranging from learning approach, applied learning models, or the use of learning media, infrastructure and facilities owned by the school. Therefore, there during the learning process teachers should be able to create a pleasant atmosphere and encourage student more enterprising, enthusiastic, creative and able to cooperate with each other. However, the efforts taken by the teacher during this time there are still many who have not produced results. Proven teachers must hold a remedial and enrichment activities.

Education is also a science that must be owned by every human being to develop the ability. Education on man, do not instantly acquired but need a process that makes knowledge awakened. This learning process cannot be separated from the learning process. One factor the ongoing success comes from students' education. Students assist educators to develop the quality of education. However, if the only educator without coupled with the willingness of the students is impossible to develop targeted education.

Based on observations and interviews that have been conducted by the Applicants with the fifth grade students and teachers in 46 Elementary School of Parepare, found the problem in the learning process among students tend to prefer to do things alone. Current events and discussion groups, only some children are active during the discussion. Students are reluctant to cooperate with each other, it is seen students who are reluctant to give opinions during the discussion and hard to accept the opinions of other students.

Another factor demonstrating the student's ability to cooperate lower that is currently underway student group activities tend to work alone and group discussions in advance with members of the group because there are some students who tend to be passive when carrying out group activities. Low school cooperation attitude are not the only problems in the classroom, but there are some problems such as the ability of students to absorb the material is still low, because students tend to learn the subject matter while in the school environment alone,

Student collaboration capabilities are important in education which takes place in the learning process, because the ability to cooperate to improve student relations for mutual respect, responsibility and caring with others. Ability to cooperate to prevent the students from the selfish attitude, because work together to create a relationship of mutual need of solidarity in achieving common goals, respect for others and concern for others. Students who have a limited understanding will be more easily understood with the help of other friends, students can broadly be asked another student, provide feedback, so as to create a state of synergy between students build knowledge. Student collaboration capabilities also help avoid the attitude of inferiority, and can train students in a relationship to be more open to other students, 
The problem of low student collaboration capabilities into a reason for reflection by involving teachers for solving the problem. One solution that can be used by selecting and determining the appropriate learning models, attractive, and can create a fun learning environment for students so that they can develop students' ability to work. By paying attention to the existing conditions, then the learning alternatives that will be implemented is to make the learning process by using cooperative learning model Number Head Together (NHT) is expected to develop students' ability to cooperate.

According to Hamdani (2011) Numbered Heads Together is a model of learning by way each student is given a number and made a teachers group was then randomly call numbers of students. This type was developed by Spencer Kagen to involve more students in studying the material covered in the lesson and check their understanding of the subject content (Priansa, 2015). This method guarantees the involvement of all students, which is very good to increase the responsibility of the individual in the group.

The advantage to using NHT type cooperative learning model that is each student's learning process so earnestly, every student be ready for all, students who are good to teach students who are less intelligent, and no student is dominate during the learning.

Based on the above, the research done by applying cooperative learning model Number Head Together in an attempt to overcome the lack of cooperation in 46 Elementary School of Parepare. The Number Head Together cooperative learning model is used because there is an element in the learning process of cooperation that should be owned by every student. At the time of implementation of learning, each student must work together in a group so that the implementation of learning to walk according to the instructions given by the teacher. Learning the Number Head Together cooperative model is expected to increase the cooperation of students in primary schools 46 Parepare.

A. Formulation of the problem

Based on the above background, it is the problem in this research are as follows:

1. How is the implementation of cooperative learning model of Numbered Head Together against students in Parepare 46 Public Elementary School?

2. How is the collaboration capabilities of students in Parepare 46 Public Elementary School?

3. Is there a significant effect using cooperative learning model Numbered Head Together towards collaboration capabilities of students in primary schools 46 Parepare?

B. Research purposes

1. To describe the implementation of cooperative learning model Numbered Head Together in Parepare 46 Public Elementary School.

2. To reveal the collaboration capabilities of students in Parepare 46 Public Elementary School.

3. To know there is significant use of cooperative learning model Numbered Head Together towards collaboration capabilities of students in primary schools 46 Parepare. 


\section{Method}

\section{Types of research}

The research approach is one important aspect in the continuity of research to be conducted. This is because research approach affect the way researchers solve the problems of an examined. The approach in this study using a quantitative approach to the type of research is quasi-experimental. A quantitative approach chosen for solving the problem must be in accordance with the formulation of a problem that requires the calculation and measurement of variables and testing of hypotheses that have been set. According to Arifin (2011: 29):

Quantitative research is research used to address the problem through a technique careful measurement of certain variables, resulting in conclusions that can be generalized, separated from the context of the time and the situation and the type of data collected mainly quantitative data.

The research method is a method used in a study to achieve the research objectives. The research method or often referred to as the research methodology is a design or design of the study. According Sugiyono (2008: 3) "research method is a scientific way to get data with a specific purpose and usefulness".

The purpose of this study was to determine the effect of the use of cooperative learning model Numbered head together towards student collaboration. Based on the research objectives to be achieved then the method used in this study experimental - quasi design with pre-test and post-test. A quasi-experimental quasi-experimental research, because of the requirements - requirements as experimental research is not sufficient enough that no randomization.

\section{Research Variables and Operational Definitions}

According Sugiyono (2015) says that the study variables was everything any shape defined by the researchers to be studied in order to obtain information about it, then drawn conclusions. The variables are basic terms in experimental research, including research with a single subject. The variable is an attribute or characteristic of something observed in the study.

There are two variables in this study, namely the independent variable (independent) and the dependent variable (dependent). These variables are as follows:

1) The independent variable

The independent variables are variables that affect other variables. The independent variable in this study cooperative learning model Numbered Head Together (X).

2) Dependent variable

The dependent variable is the variable that is affected because of their independent variables. The dependent variable in this study is the cooperation of students (Y).

An operational definition is a description that contains a variable number of indicators that can be observed and measured to identify two variables or concepts to use in this study is work together student and group counseling with cooperative learning model Numbered head together.

1) Cooperative learning model Numbered Head together consist of several procedures, namely (a) the numbering (numbering), (b) questioning (ask), (c) head together (think together) (d) answering (answered).

2) Collaboration capabilities of students is the willingness of self, skill, and force to act between two or more people to mutually work together to achieve a common goal that is sketched on students during the learning activities that include (1) is 
responsible for the assignment, (2 ) helping a friend in the group, (3) provide an opinion, (4) receiving the opinion, (5) solve the problem group, (6) completing the task group.

\section{Research design}

One of the activities in experimental research is to determine the design of experiments. In this study design using the Control group pretest-posttest design, because in this design involves two groups: the experimental group and the control group. In the experimental group was given a pretest before being given treatment (treatment) is then given a posttest after being given treatment (treatment). The design can be described as follows:

Table 1. Research Design.

\begin{tabular}{|l|l|l|l|}
\hline Group & pretest & Treatment (Variables) & Posttest (Variable Bound) \\
\hline Experiment & O1 & X & O2 \\
\hline Control & & & O4 \\
\hline
\end{tabular}

Information:

O1 : Pretest experimental class

$\mathrm{O} 2$ : Experiment class posttest

O3 : Class pretest control

$\mathrm{O} 4$ : Posttest control class

$\mathrm{X}$ : Treatment of the experimental class

Such research designs, done by researchers with how to determine the group that acts as an experimental class and control class

\section{Population and Sample}

\section{a. Population}

Population according to Sugiyono (2010: 117) is "generalization region consisting of the object or subject that has certain qualities and characteristics defined by the researchers to learn and then drawn conclusions". Meanwhile, according to Arifin (2012: 215) of the population is "the whole object under study, either in the form of people, objects, events, values and the things that happen".

Based on the explanations above, the population in this study is 46 Parepare Elementary School students in the academic year 2018/2019 consists of six study groups with the number of students 191. Researchers will not take the amount of the overall population, but only take samples only, in order to subject study not too much. The following number of students of 46 Parepare Elementary School 
Table 2. list of Students at Parepare Elementary School.

\begin{tabular}{|l|l|l|}
\hline NO & Class & Amount \\
\hline 1 & I & 33 \\
\hline 2 & II & 29 \\
\hline 3 & III & 33 \\
\hline 4 & IV & 33 \\
\hline 5 & V & 30 \\
\hline 6 & VI & 33 \\
\hline
\end{tabular}

b. samples

The sample is representative of the population. Sampling is intended to allow research to take place effectively and efficiently. Technique Sampling was done by using purposive sampling, the sampling technique intentionally because there are considerations certain (Sugiyono, 2006: 61), The requirements that must be met in determining the sample based on certain considerations, namely:

Sampling should be based on the characteristics, qualities or specific characteristics, which are the fundamental characteristics of the population.

Subjects were sampled really a subject that most contain the features found in the population. Determination of the characteristics of the population carried out carefully in the preliminary study.

Based on the above opinion, the samples taken is a class $\mathrm{V}$ with the number of 30 students, consisting of as many as 14 male and female students as many as 16 students, with consideration that a fifth grade class with the level of cooperation skills of students less well than the other classes.

\section{c. Data collection technique}

In a study of data are very important. Therefore, the data should be collected by the data collection techniques or methods accordingly. Collecting data in the study is expected to obtain materials, information, facts, and information that can be trusted. The data collected in this study include sheets observation, questionnaire and documentation.

a. Observation

The observations were made to observe and record events that occur during the learning process. Observations addressed to teachers and students with the aim of observing the activity of students and teachers in learning using cooperative learning model Numbered heads together and observation also made to see or observe the cooperation of student learning using cooperative learning model of Numbered Head Together. Correspondingly, Sugiyono (2013: 203) that the observation is used to measure the activity and human behavior.

b. questionnaire

Questionnaire was used for data collection on research. Questionnaire (questionnaire) is a technique of data collection is done by giving a set of questions or a written statement to the respondent to answer. The questionnaire is an efficient data collection technique if researchers know for certain variables to be measured and know what can be expected from the respondents.

Interest questionnaire is to find complete information about a problem and respondents without worrying if the respondent gave an answer that does not correspond to 
reality in filling out the questionnaire. In addition, respondents know information requested certain the number of statements in the questionnaire with five choices, Always (SL), often (S), sometimes (K), rare (JR), never (TP). The questionnaire is an efficient data collection technique if researchers know for certain variables to be measured and know what can be expected from the questionnaire.

c. Documentation

Documentation is the collection of data by researchers by collecting documents from reliable sources who know about the informant. Documentation of this study is shooting by researchers to reinforce the research results. Sugiyono (2013: 240) documentation can take the form of writing, pictures or works of monumental from someone. Implementation of this research documentation in the form of field notes, lesson plan (RPP), teaching materials, test results, learning achievement sheet and photos of activities.

2. Engineering Data Analysis

a. Descriptive statistical analysis

These descriptive statistics are methods relating to the collection, summarizing, and presenting the data so as to provide useful information and arranging them into a form that is ready for analysis. In other words, these descriptive statisticsused to describe the characteristics of each of the variables using the frequency distribution table then determine the average (mean), median, mode, standard deviation, and percentage achievement of learning.

b. Inferential statistical analysis

Inferential statistical analysis was used to analyze the data sample and the results are applied to the population. This analysis includes data normality test, homogeneity test data, and test hypotheses.

a. Normality Test Data

This test is used to determine whether the sample is from a population that is normal or not, Normal here in the sense of having a normal distribution. Normal or not based on the normal benchmark of the data with the mean and standard daviasi same. So normality test basically do a comparison between the data we have with the normal distribution of data which has a mean and standard daviasi with our data.

The hypothesis proposed to measure the normality of the distribution of the population in this study as follows:

HO : Normally distributed data.

H1 : Data is not normal.

Basis for a decision in the normality test is:

- If the value of $\mathrm{Sig}>0.05$, then Ho is accepted, the data were normally distributed.

- If the value of Sig $<0.05$, then H1 is received, the data are not normally distributed

b. homogeneity test

Homogeneity test is performed to determine variants of data from several populations, together or not, and as a precondition for an independent analysis of samples $t$ test. The homogeneity test is used as a reference for determining the statistical test decisions or to determine the homogeneity of the experimental class and control class, it aims to see whether the student's ability experimental class and control class before the treatment is the same or not. The hypothesis proposed to measure the homogeneity of the population in this study as follows: 
Ho : Data homogeneous population.

H1 : Data population is not homogeneous.

- If the value of Sig> 0.05, then Ho is accepted, it is said that a variant of the two groups of data population is homogeneous.

- If the value of Sig $<0.05$, then $\mathrm{H} 1$ is said that a variant of the two groups of data population is not homogeneous.

c. Hypothesis testing

Hypothesis testing is performed with SPSS 16.0 for Windows, and using the formula test (t-test independent). Because only testing or comparing two samples and the control and experimental groups. There are a couple of t-test formula to use them as follows:

$$
t=\frac{X_{1}-X_{2}}{s \sqrt{\frac{1}{n_{1}}+\frac{1}{n_{2}}}}
$$

Information:

$\mathrm{X} 1$ : The average group experiment

$\mathrm{X} 2$ : The average group control

$\mathrm{S} \quad$ : standard deviation

n1 : The number of members of the experimental class

n2 : The number of class members control

Furthermore, to find the value of s using the formula:

$$
s=\sqrt{\frac{(n 1-1) s 1^{2}+(n 2-1) s 2^{2}}{(n 1+n 2)-2}}
$$

Information:

s12 = Variance of the experimental group

s22 = Variance group control

$\mathrm{n} 1=$ The number of members of the experimental group

$\mathrm{n} 2=$ The number of members of the class control

The purpose of testing this hypothesis is to compare whether the two data (variables) are the same or different. As for being compared to the test this hypothesis are scores of pretest and post-test between the experimental group and control group as a whole regarding the cognitive learning outcomes of students.

Next, determine the degrees of freedom (df) by the formula: $(n 1+n 2-2)$. And determining the value $t$-count compared with t-table at significance level $\alpha=0.05$ with the provisions of the following hypotheses:

If $\mathrm{t}<\mathrm{t}$-table, then the hypothesis $\mathrm{H} 0, \mathrm{H} 1$ is rejected if $\mathrm{t}$ count $>\mathrm{t}$-table, then $\mathrm{H} 0$ is rejected, accepted $\mathrm{H} 1$ 


\section{Result and discuss}

In the discussion outlined the findings - findings of the research data on the effect of the application of cooperative learning model Numbered Head together against class collaboration capabilities of students in the control and the experimental class students in 46 Parepare Elementary School to notice any difference in students' ability to cooperate. Inferential test data analysis results between the experimental class and control class using the $t$ test calculations (hypothetical) type of independent sample test. Before the test the hypothesis then tested the normality and homogeneity test data through the application of SPSS version 16 for windows as a prerequisite of data worthy of tested hypotheses.

In the data normality test, post-test results data regarding students' ability to cooperate in the control class and experimental class data shows normal distribution, and data that have been tested there is no difference variance 1 and 2 so that the data is said to be homogeneous. Having tested the normality and homogeneity, the next step is testing the hypothesis through independent sample test. The results of hypothesis testing through SPSS tailed sig 2 is 0,000 . It can be served with a p value of $0.000<0.05$, which means that Ho refused and Ha accepted which means there is differences in the average students ability to cooperate between students who learn to use the implementation of cooperative learning model Numbered Head Together with students studying without using the implementation of cooperative learning model Numbered Head Together, In the statistical group table looks average - average (mean) for the control group was 70.60 and the experimental class is 83.40 , meaning that the value - average ability to cooperate experimental class is higher than the control class. The average difference (mean difference) equal to 12.8 and the difference ranges from 1.37.

Based on data from the results of this study concluded that there the average difference in students' ability to cooperate between students who learn to use the implementation of cooperative learning model Numbered Head Together with students studying without using the implementation of cooperative learning model Numbered head together. Thus, through the implementation of cooperative learning model Numbered Head together students have the potential to work together to solve the problems given. In addition, studies using the implementation of cooperative learning model Numbered Head together carried out showed that the study results mean posttest experimental class using NHT learning model application amounted to 83, 40 (both criteria at all).

Based on data from this study and discussion it can be concluded that the study results in line with hypotheses formulated by researchers that "there are differences in the ability to cooperate between students learning through the implementation of cooperative learning model Numbered Head together with the students to learn without the implementation of cooperative learning model Numbered Head together in 46 Parepare Elementary School". It showed no effect of the application of cooperative learning model Numbered head together towards student collaboration capabilities.

\section{Conlussion}

1. The implementation of cooperative learning model Numbered Head together in 46 Parepare Elementary School already performing well and are in accordance with the stages of learning.

2. Student collaboration capabilities of prior learning through the implementation of cooperative learning model Numbered heads together in the category of students and 
ability to cooperate after the implementation of cooperative learning model Numbered heads together at the high category.

3. There is the influence of the implementation of cooperative learning model Numbered head together towards collaboration capabilities of students in primary schools 46 Parepare.

\section{References}

[1] Somov, A.: Wildfire safety with wireless sensor networks. EAI Endorsed Transactions on Ambient Systems. pp. 1-11 (2011)

[2] Motaz, A.: Start programming using Object Pascal. Vol. 2, pp. 10-11. Legally Free Computer Books, US (2013) 